\title{
Effect of Prenatal Yoga on Changes in Fetal Position in Pregnancy
}

\author{
Weni Tri Purnani, Miftakhul \\ Mu'alimah \\ Bachelor of Midwifery, Faculty \\ of Health Sciences, Kadiri \\ University \\ Email: \\ wenitripurnani@unik-kediri.ac.id
}

Received : October $4^{\text {nd }} 2021$

Accepted : October $15^{\text {rd }} 2021$

Published : November $27^{\text {th }} 2021$

\begin{abstract}
Based on a preliminary study, there were $18.31 \%$ who had a breech delivery, it would result in complications in the baby such as asphyxia, bleeding or soft tissue edema, damage to the medulla oblongata, damage to the cervical spine joints, and even death due to severe asphyxia. determine the effect of Prenatal Yoga on Changes in Fetal Position in Pregnant Women. This type of observational research uses a quasi-experimental design with pretest and post-pest with control group design. The research was conducted in the city of Kediri. The sample in this study was 32, namely third trimester pregnant women with gestational age $>28$ weeks who experienced breech, latitude, and obligate fetal positions which were divided into 2 groups of 16 intervention groups (Prenatal Yoga) and 16 people as controls (pregnancy exercise). The sampling technique used is simple random sampling. Bivariate analysis using Mann Whitney Test. The results obtained are $\mathrm{Z}=-2.626$ and -value $0.009<0.05$ so that $\mathrm{Ho}$ is rejected and it can be concluded that there is an effect of Prenatal Yoga on Changes in Fetal Position in Pregnant Women in Kediri City. Yoga exercises to help change the position of the fetus are more focused on providing a wide space in the abdomen, flexing the muscles of the uterus and pelvis. Three movements were used in this study, namely cat cow, downward-facing dog and puffy pose. Suggestions for health workers that prenatal yoga can be a solution and can be applied to help change the position of the fetus from malpresentation to head position.
\end{abstract}

Keywords: Prenatal yoga, fetal position, breech presentation

Copyright @ 2021 IIK STRADA Indonesia All right reserved.

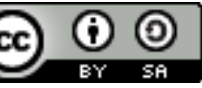

This is an open-acces article distributed under the terms of the Creative Commons AttributionShareAlike 4.0 International License.

\section{INTRODUCTION}

Maternal Mortality Rate (MMR) is one indicator to see the success of maternal health efforts. In general, there was a decrease in maternal mortality during the period 1991-2015 from 390 to 305 per 100,000 live births. Although there is a tendency to decrease maternal mortality, the MDGs target that must be achieved is 102 per 100,000 live births in 2015. The results of the 2015 SUPAS show that the maternal mortality rate is three times higher than the MDGs target. The number of maternal deaths by province in 2018-2019 decreased from 4,226 to 4,221 maternal deaths in Indonesia. In 2019 the most common causes of maternal death were bleeding (1,280 cases), hypertension in pregnancy (1,066 cases), infection (207 cases) details per province (Indonesian Health Profile, 2019). Based on a preliminary study conducted by researchers in the Maternity Room of Aura Syifa Hospital, Kediri, 
especially in women who gave birth in April 2019 there were $18.31 \%$ who had a breech delivery. ), narrow pelvis in 5 cases $(19.23 \%)$, premature in 2 cases $(7.69 \%)$, gemelli in 3 cases $(11.54 \%)$, and hydramnios in 3 cases (11.54\%). Based on these data, it can be concluded that there are mothers who experience a breech position in the city of Kediri. The direct impact will result in complications for the mother such as bleeding, tearing of the birth canal and infection. In addition, it will also cause complications in infants such as asphyxia, bleeding or soft tissue edema, damage to the medulla oblongata, damage to the cervical spine joints, and even death due to severe asphyxia (Yanti, 2010). The solution that can be done is to routinely do prenatal yoga, which can increase blood flow and fetal nutrition adequately and also affect the mother's reproductive organs and pelvis (strengthen the perineal muscles) to prepare for the birth of a child naturally. In addition, prenatal yoga can reduce edema and cramps that often occur in the last months of pregnancy, help the baby's position and movement, improve digestion and appetite, increase energy and slow down metabolism to restore calm and focus, reduce nausea, morning sickness and mood, relieves calm around the cervix and birth canal, which focuses on opening the pelvis to facilitate labor, assists in the postnatal period by restoring the uterus, abdomen and pelvic floor, reducing tension, anxiety and depression during pregnancy, parturition and breast discomfort ( chopra \& Simon, 2004; Stoppard, 2008; Amy \& Kathryn. 2008; Siska, 2009; Shindu 2009; Wiadnyana, 2011). The purpose of this study was to determine the effect of Prenatal Yoga on Changes in Fetal Position in Pregnant Women.

\section{MATERIALS AND METHODS}

Based on the research objectives, it is an observational type using a quasi-experimental design with pre-test and post-pest with control group design. The research was conducted in the city of Kediri. The sample in this study was 32 respondents who experienced breech, latitude, obligate fetal position which were divided into 2 groups, 16 people in the intervention group (Prenatal Yoga) and 16 people as controls (pregnancy exercise). Respondents consisted of two treatment groups and a control group. Both groups underwent a special examination by an obstetrician to determine if the pregnancy was normal and prenatal yoga could be performed. The sample has been homogenized, namely pregnant women in the third trimester of gestation > 28 weeks, who have a breech, latitude, oblique position of the fetus, there are no pregnancy complications. The intervention in the treatment group used gentle yoga prenatal SOPs. The intervention group was given prenatal gentle yoga treatment every day for 60 minutes until day 14. Meanwhile, the control group was treated with pregnancy exercise every day for up to 14 days. The sampling technique used is simple random sampling. Prenatal Yoga is the independent variable and Fetal Position Change is the dependent variable in this study. The instrument used in this study was an observation sheet. Data analysis was carried out in stages using univariate and bivariate analysis. Bivariate analysis using the Mann Whitney test with a value of $5 \%$ or 0.05 . The ethical review was carried out prior to the implementation of the research.

\section{RESULTS}

Table 1 Distribution of Fetal Location Before Treatment

\begin{tabular}{ccccc}
\hline Fetal Location & \multicolumn{2}{c}{ Intervention Group } & \multicolumn{2}{c}{ Control Group } \\
\cline { 2 - 5 } & $\mathrm{f}$ & $\%$ & $\mathrm{f}$ & $\%$ \\
\hline Malpresentation (breech, latitude, oblique) & 16 & 100 & 16 & 100 \\
Normal Presentation (Head) & - & - & - & - \\
\hline Total & 16 & 100 & 16 & 100 \\
\hline
\end{tabular}

(Source: Primary Data 2020)

Based on table 1, it can be seen that the intervention group and the control group all experienced malpresentations, namely 16 respondents each (100\%)

Table 2 Distribution of Fetal Location After Treatment

\begin{tabular}{ccccc}
\hline Fetal Location & \multicolumn{2}{c}{ Intervention Group } & \multicolumn{2}{c}{ Control Group } \\
\cline { 2 - 5 } & $\mathrm{f}$ & $\%$ & $\mathrm{f}$ & $\%$ \\
\hline Malpresentation (breech, latitude, oblique) & 2 & 12.5 & 13 & 81.25 \\
Normal Presentation (Head) & 14 & 87.5 & 5 & 31.3 \\
\hline Total & 16 & 100 & 16 & 100 \\
\hline
\end{tabular}


(Source: Primary Data 2020)

Based on table 2, it can be seen that the majority of respondents experienced a normal presentation of the fetus in the intervention group, namely 14 respondents (87.5\%), while in the control group, there were 5 respondents $(31.3 \%)$.

Table 3 Analysis of the Effect of Prenatal Yoga on Changes in Fetal Position in Pregnant Women

\begin{tabular}{|c|c|c|c|c|c|c|}
\hline \multirow[t]{3}{*}{ Group } & \multicolumn{4}{|c|}{ Fetal Location } & \multicolumn{2}{|c|}{ Total } \\
\hline & \multicolumn{2}{|c|}{$\begin{array}{l}\text { Malpresentation (breech, } \\
\text { latitude, oblique) }\end{array}$} & \multicolumn{2}{|c|}{$\begin{array}{c}\text { Normal } \\
\text { Presentation (Head) }\end{array}$} & \multirow[b]{2}{*}{$\mathrm{N}$} & \multirow[b]{2}{*}{$\%$} \\
\hline & $\mathrm{N}$ & $\%$ & $\mathrm{~N}$ & $\%$ & & \\
\hline $\begin{array}{l}\text { Intervention (Doing Prenatal Yoga with } \\
\text { Prenatal Gentle Yoga) }\end{array}$ & 2 & 12,5 & 14 & 87.5 & 16 & 100 \\
\hline Control (Pregnant Gymnastics) & 13 & 81.25 & 5 & 31,3 & 16 & 100 \\
\hline \multicolumn{5}{|c|}{ Total } & 32 & 100 \\
\hline \multicolumn{7}{|c|}{$\alpha=0,05 ; Z=-2,626 ; \rho$-value $=0,009 ; \rho<0,05$} \\
\hline
\end{tabular}

(Source: Primary Data 2020)

Berdasarkan tabel 3 dapat diketahui bahwa hasil uji Analisis Pengaruh Yoga Prenatal Terhadap Perubahan Letak Janin pada Ibu Hamil di Kota Kediri Tahun 2020 dengan menggunakan uji Mann Whitney didapatkan hasil nilai $\mathrm{Z}=-2,626$ dan $\rho$-value $0,009<0,05$ sehingga Ho ditolak dan dapat disimpulkan bahwa terdapat Pengaruh Yoga Prenatal Terhadap Perubahan Letak Janin pada Ibu Hamil di Kota Kediri Tahun 2020

\section{DISCUSSION}

The results of this study indicate that there is an effect of prenatal yoga on changes in fetal position in third trimester pregnant women, because yoga during pregnancy has great benefits in maintaining both emotional and physical health and shows a decrease in pain, stress, the occurrence of prenatal disorders and gestational age. small. Yoga is also rated as a more effective exercise than walking or other standard prenatal exercises. Prenatal yoga also helps the mother's labor process become a positive experience that mothers experience by increasing muscle strength, increasing energy reserves and flexibility. Yoga works by preparing a woman's body to undergo the labor process she will go through (Aprillia, 2015).

Abnormal fetal positions such as breech, transverse and obligatory positions can be corrected by means of the knee chest position (chest-knee position) in the mother and the external version related to maternal posture. Midwives in general will advise the mother to do a knee chest position in order to change the position of the fetus from breech to normal because this is the easiest for pregnant women to do (Prawirohardjo, 2012). In addition to knee chest, currently developing physical exercise or gymnastics that can be done by pregnant women to create a wide abdominal space for the fetus, namely doing prenatal yoga movements. With careful preparation, physically and mentally, the mother will be more confident and gain confidence in having a smooth and comfortable delivery. To get optimal results, this yoga practice is done regularly, so there is a time span needed to get optimal results.

According to the research results of Narendran, Nagarathna, Narendran, Gunasheela, \& Nagendra (2005) that adherence to a yoga practice program reduces the possibility of complications during pregnancy and facilitates the delivery process. Prenatal yoga physical activity is a relation between yoga and body anatomy, both of which have a connection that comes from a fairly simple thought, namely the existence of the deepest principle in yoga which is based on an appreciation of the human body system begins (Rusmita, 2015). Prenatal yoga movements provide more room for the baby. The benefits of yoga are not only for the mother but also for the baby. Many yoga poses help make room for the baby. Your baby will be able to grow and develop with more space and oxygen. Yoga teaches the correct position to allow the most space for the baby (Sindhu, 2011). Specific movements in prenatal yoga aim to strengthen the muscles and organs associated with pregnancy and birth. This exercise forms the physical readiness of pregnant women to prepare themselves physically and pregnant women's stamina for childbirth. Muscle flexibility in pregnant women also has a positive impact where the 
muscle stiffness that is often felt by the mother is lost, the mother's muscles become comfortable during the pregnancy process. and of course it will be able to facilitate the process of giving birth to the baby (Aprilia, 2014).

Yoga exercises to help change the presentation of the fetus are more focused on providing a wide space in the abdomen, flexing the muscles of the uterus and pelvis. Three movements were used in this study, namely cat cow, downward-facing dog and puffy pose. The downward-facing dog movement is a movement that can stimulate the baby's return from a breech position to a normal position for childbirth by lifting the buttocks and abdomen of pregnant women with the help of the legs and arms so that the position of the pregnant women's buttocks will be higher than the lower facing dog. his head. This movement also utilizes the earth's gravity to help rotate the fetal head. Changes in fetal presentation during pregnancy are influenced by physical forces acting on the uterus and fetus. Physical forces acting on the fetus in the uterus include gravity, buoyancy, and friction. Through the force of gravity, the earth attracts particles of matter. The force of gravity on the fetus acts on various parts of the fetal body with different forces based on the density and mass of the fetal body parts. The downward movement of the fetus follows the path of action of gravity for the entire fetus through the center of gravity. For the application of this theory, it is assumed that the ovoid shape of the fetus in the uterus is surrounded by amniotic fluid. The weight of the fetus acts on the center of gravity. This causes the buttocks of the big and heavy legs to be pulled down when the mother does this position with the pelvis higher than the shoulders meaning the fundus position is lower than the cervix. So the buttocks of the legs will be attracted to the fundus (Jamieson, 2004).

The cat cow movement has the benefit of flexing the muscles that support the uterus and uterine muscles so that they are not tense. This flexibility will reduce the emphasis on the mother's abdominal area so as to provide breadth for the fetus to move in the womb (Aprilia, 2014). The puffy pose movement also aims to raise the pelvic area and provide space for the mother's abdomen so that it can make the baby move to turn his head in a breech position. Puffy pose movements also take advantage of the earth's gravity to help rotate the fetus. Previous studies have used the yoga treatment for another effect. Aryani, Handayani, \& Susilowati's research (2018) shows that there is an effect of the implementation of prenatal gentle yoga on anxiety before childbirth in primigravida pregnant women. Thus, it can be used in pregnant women who experience anxiety before delivery as a form of non-pharmacological treatment. A similar study was conducted by Smith, Crowther, Wilkinson, Pridmore, \& Robinson, (1999), but this study only treated pregnant women with breech presentation with knee-chest. A randomized clinical trial recruiting 100 women from two hospitals in Adelaide, South Australia, with a singleton breech presentation and gestational age equal to or more than 36 weeks found that postural management (knee-chest) did not increase the efficacy of the external cephalic version or unable to reduce the frequency of breech presentations. Meanwhile, this study obtained the results that almost half $(43.7 \%)$ of the breech fetal position became normal (head) on $>12$ days and $75 \%$ of the fetal presentation from the buttocks to the head could occur at weeks $1-3$, with details $<7$ days is $25 \%, 8$ 14 is $37.5 \%, 15-21$ days is $18.7 \%$ and the rest is $>21$ days. Prenatal Yoga gives hope to pregnant women about the benefits of changing the position of the breech fetus to normal (head position). The benefit is that the mother can give birth normally and avoid abnormal, even invasive (surgery) deliveries. In addition to the effects of changes in fetal presentation, the effects of prenatal yoga have been shown to improve the overall well-being of pregnant women (Holden, Manor, Zhou, Zera, Davis, \& Yeh, 2019) and yoga during pregnancy has been shown to be safe, increase birth weight, reduce preterm labor, and reduce preterm labor. decreased IUGR either in isolation or associated with antepartum hemorrhage, without an increase in complications (Narendran, Nagarathna, Narendran, Gunasheela, \& Nagendra, 2005). Prenatal Yoga also from previous research has an effect on the physical and psychological readiness of pregnant women to give birth (Dewi, Erialdy, \& Novita, 2018; Wati, Supiyati, \& Jannah, 2018).

This study shows that there is a significant difference in changing the presentation of the fetus by doing prenatal yoga and pregnancy exercises. Prenatal yoga is more effective at helping the fetus rotate, thereby turning the fetal presentation into a head. Prenatal yoga movements make the muscles of the uterus and birth canal more relaxed and flexible so that the tension in the uterus causes the narrow abdominal space to become looser. The yoga position with the pelvis higher than the abdomen causes the wider fundus to be at the bottom near the floor. With the influence of the earth's gravity, it will pull the heavy and large part down. This means that the large and heavy part of the fetus is the buttocks and 
the adjacent legs will be forced to occupy the wide part of the uterus, namely the fundus. However, fetal movement is also influenced by the amount of amniotic fluid and the size of the fetus. Because if there is enough amniotic fluid and the baby is not too big, it will make it easier for the fetus to rotate (Aprillia, 2015). Prenatal yoga has a very good effect for pregnant women in improving the presentation of the fetus. In addition, other benefits can also be obtained such as relaxation and flexibility of the uterine muscles. For this reason, pregnant women are emphasized to do prenatal yoga for the delivery process and to prevent the breech position of the fetus and to remain in a normal position (head), even to avoid abnormal deliveries such as cesarean surgery.

\section{CONCLUSION}

Based on the results of the study, it can be concluded that there is an effect of prenatal yoga on changes in the position of the fetus in pregnant women in the city of Kediri in 2020

\section{REFERENCE}

Apriliani, R. A. (2015). Pengaruh Yoga Prenatal terhadap Kecemasan Sesaat dalam Menghadapi Persalinan pada PrimigravidaTrimester III DigaleniaMomand Baby Center Kota Bandung. Resipitory Fakultas Psikologi Universitas Islam Bandung. http://repository.unisba.ac.id/handle/123456789/357

Aryani, R. Z., Handayani, R., \& Susilowati, D. (2018). Pengaruh Pelaksanaan Prenatal Gentle Yoga Terhadap Kecemasan Menjelang Persalinan Pada Ibu Hamil Primigravida Trimester Iii Di Klinik Bidan Kita Klaten. Jurnal Kebidanan Dan Kesehatan Tradisional, 3(2), 78-83. https://doi.org/10.37341/jkkt.v3i2.85

Astuti, Y., \& Afsah, Y. R. (2019). Peningkatan Kesejahteraan Ibu Hamil dengan Prenatal Yoga. Jurnal SOLMA, 8(1), 47-53. https://doi.org/10.29405/solma.v8i1.2966

Dewi, R. S., Erialdy, E., \& Novita, A. (2018). Studi Komparatif Prenatal Yoga dan Senam Hamil terhadap Kesiapan Fisik. Jurnal Ilmu Kesehatan Masyarakat, 7(3), 155-166. https://doi.org/10.37341/jkkt.v3i2.85

Holden, S. C., Manor, B., Zhou, J., Zera, C., Davis, R. B., \& Yeh, G. Y. (2019). Prenatal yoga for back pain, balance, and maternal wellness: a randomized, controlled pilot study. Global advances in health and medicine, 8, 2164956119870984. https://doi.org/10.1177/2164956119870984

Hunter, S., Hofmeyr, G. J., \& Kulier, R. (2007). Hands and knees posture in late pregnancy or labour for fetal malposition (lateral or posterior). Cochrane database of systematic reviews, (4).https://doi.org/10.1002/14651858.CD001063.pub3

Indiarti, M.,T. (2009). Panduan Lengkap Kehamilan, Persalinan dan Perawatan Bayi. 10thed. Yogyakarta: Diglossia Media.

Manuaba, I.A.C., Manuaba, I.B.G.F., \& Manuaba, I.B.G. (2007). Pengantar Kuliah Obstetri. Jakarta : Buku Kedokteran EGC

Mirriam, S. (2008). Conception Pregnancy And Birth. New York : Dorling Kindesley (DK)

Narendran, S., Nagarathna, R., Narendran, V., Gunasheela, S., \& Nagendra, H. R. R. (2005). Efficacy of yoga on pregnancy outcome. Journal of Alternative \& Complementary Medicine, 11(2), 237-244. https://doi.org/10.1089/acm.2005.11.237

Neri, I., De Pace, V., Venturini, P. \& Facchinetti, F. (2007). Effects of Three Different Stimulations (Acupuncture, Moxibustion, Acupuncture Plus Moxibustion) of BL.67 Acupoint at Small Toe on Fetal Behavior of Breech Presentation 
Notoatmodjo, S. (2010). Metodologi Penelitian Kesehatan. Jakarta : Rineka Cipta

Prawirohardjo, S. (2014). Ilmu Kebidanan Sarwono Prawirohardjo. 4th ed . (Saifudin AB, ed.). Jakarta: PT. Bina Pustaka Sarwono Prawirohardjo.

Pujiastuti, S. (2011). Yoga Untuk Kehamilan : Sehat, Bahagia dan Penuh Makna. Bandung : Mizan

Putra, B. A., Suparman, E., \& Tendean, H. M. (2016). Gambaran persalinan letak sungsang di RSUP Prof. Dr. RD Kandou Manado. e-CliniC, 4(2). https://doi.org/10.35790/ecl.v4i2.12798

Oxorn, H., Forte, W. R. (2010). Presentasi bokong. In: Ilmu Kebidanan: Patologi \& Fisiologi Persalinan. Yogyakarta: Andi Offset.

Rusmita, E. (2015). Pengaruh senam hamil yoga terhadap kesiapan ibu hamil menghadapi persalinan di RSIA Limijati Bandung. Jurnal Keperawatan BSI, 3(2). https://doi.org/10.31311/.v3i2.155

Silinaung, M. D. G., Kaeng, J. J., \& Suparman, E. (2016). Karakteristik persalinan letak sungsang di RSUP Prof. Dr. RD Kandou Manado periode 1 Januari 2014-31 Desember 2014. eCliniC, 4(1).https://doi.org/10.35790/ecl.v4i1.10984

Smith, C., Crowther, C., Wilkinson, C., Pridmore, B., \& Robinson, J. (1999). Knee-chest postural management for breech at term: a randomized controlled trial. Birth, 26(2), 71-75. https://doi.org/10.1046/j.1523-536x.1999.00071.xThe American Journal Of Chinesse Medicine. 35(01), 27-33. https://doi.org/10.1142/S0192415X0700459X

Theresa, J. (2004). Yoga For Pregnancy. Dingley Australia: Hinkler Books Pty ltd

Wati, N. W. K. W., Supiyati, S., \& Jannah, K. (2018). Pengaruh Senam Yoga terhadap Kesiapan Fisik dan Psikologis dalam Menghadapi Persalinan di BPM Lasmitasari, S. ST. Jurnal Kedokteran dan Kesehatan, 14(1), 39-47. https://doi.org/10.24853/jkk.14.1.39-47

Wiknjosastro, H. (2005). Ilmu Kebidanan (4th ed). Jakarta: Yayasan Bina Pustaka Sarwono Prawirohardjo.

Yessie, A. (2014). Gentle Birth Balance. Bandung : Mizan

Zulaikha, L. I., \& Apidianti, S. P. (2017). Hubungan Paritas Ibu Bersalin Dengan Kejadian Letak Sungsang di BPS

Suhartatik Wilayah Kerja Puskesmas Talang. SAKTI BIDADARI (Satuan Bakti Bidan Untuk Negeri), 1(2), 1-7. https://doi.org/10.31102/bidadari.2017.1.2.1-7 